\title{
THE EFFECTS OF STUDENTS' VOCABULARY AND GRAMMAR MASTERY TOWARDS ENGLISH RECOUNT WRITING SKILL IN THE SECOND GRADE OF PRIVATE JUNIOUR HIGH SCHOOL IN TANGERANG
}

\author{
Erni Susianti Nainggolan \\ Universitas Pamulang, Banten \\ ernin94@gmail.com
}

\begin{abstract}
The purpose of this research is to obtain empirical data about the effects of students' vocabulary and grammar mastery towards English recount writing skill. There are the effects of students' vocabulary $\left(\mathrm{X}_{1)}\right.$ and grammar mastery $\left(\mathrm{X}_{2}\right)$ towards students' English recount writing skill $(\mathrm{Y})$. That is proved by the result Fobservedis 679.878 with significance probability level is $\mathrm{Sig}=0.000$. Moreover, probability value is $(0.000)$ less than 0.05 . It means the regression model is able to be used to predict the students' skill in writing. The result of data analysis that is the multiple regression in which the multiple correlation coefficient is ( R ) is 0.987 or $\left(\mathrm{ryx}_{1 \times 2}=0.987\right)$. It means it gives strong effects among them. And the simultaneous contribution of perception on the teacher's competence and grammar mastery towards students' writing skill is $\mathrm{R}^{2} \times 100 \%$ or $0.987^{2} \times 100 \%$ $=97.4 \%$ and the rest $2.6 \%$ determined by the other factors. In conclusion $\mathrm{H}_{0}$ is rejected and $\mathrm{H}_{1}$ is accepted significantly. There is no effect of students' vocabulary $\left(\mathrm{X}_{1}\right)$ toward students' English recount writing skill $(\mathrm{Y})$. It can be proved tobserved 1.574 meanwhile table $=1.69$. Because of the score of Sig $>0.05$ $(0.124>0.05)$ and tobserved $<$ table $(1.57<1.69)$. The score of $\mathrm{Sig}=0.124$ means $\mathrm{H}_{0}$ is accepted it means that there is no significant effect of student's vocabulary toward students' English recount writing skill. From the test of correlation and regression it can be concluded that there is no effect of students' vocabulary towards students' English recount writing skill. There is an effect between grammar mastery $\left(\mathrm{X}_{2}\right)$ toward students' writing skill $(\mathrm{Y})$. It can be proved by tobserved 14.718 meanwhile table $=1.69$. Because of the score of $\operatorname{Sig}<0.05$ $(0.000<0.05)$ and $t_{\text {tobserved }}>$ table $(14.718>1.69)$ determination of regression significance criteria is the score of $\mathrm{Sig}=0.000$ means $\mathrm{H}_{0}$ is rejected. It means that there is a significant effect of grammar mastery towards students' English recount writing skill.
\end{abstract}




\section{INTRODUCTION}

English as an international language is known and used everywhere in the world. It is a great significance for people to be on top of spoken and written. English so as to be ready to come across and participate in social activities within the community. Since English is used as a compulsory subject at Indonesian schools, the students need to master English language. The schools in Indonesia teach English as the first foreign language for Indonesian students. English is chosen to be taught in Indonesian schools as the first foreign language by government of Indonesia, because it is a prior course from elementary school to university. How necessary it is.

Listening, speaking, reading, and writing are four language skills which learnt and mastered by students. There are obstacles or problems concern with the language skills and language components as mentioned before, which are faced by students later. Writing is the fourth skill mentioned among the three other language skill. Teaching writing requires the mastery not only for the vocabularies but also grammatical, theoretical devices and conceptual aspects. Based on the concept and the components of language, specifically on vocabulary, structure, and pronunciation, students should be well supported to master those aspects.

It is necessary to know that writing is a process. Students need to practice. They have to learn grammatical aspects as the fundamental organizing principle of language. Learning English grammar provides a basis for learning language, such as tenses, subjects, verb agreements, proper used of conjunction, parallel structures, kinds of sentences, and sentence patterns. One of the ways to master English is to train through writing skill that requires being practice repeatedly. Without any efforts, logical mind, nor hand, it is impossible for anyone can write by oneself. Moreover, every single word, word structure, or even punctuation in sentences must be shown in order to form words or sentences. Writing is not just production of text, it is also learning and trying out the ideas on papers, to choose the proper words.

For these explanations above the researcher would like to have a survey study on the relation between students' vocabulary and grammatical mastery towards their skills in writing text. There some kinds of text such as recount, descriptive, narrative, report, etc. Here, the researcher would like to conduct a research about the effect of vocabulary and grammar

mastery towards English recount text under the title the effects of students' vocabulary and grammar mastery towards English recount writing skill in the second grade of private junior high school in tangerang.

The respondents of this study is the second grade students. The mastery indicator of writing recount text is when students can arrange the sentence properly and correctly to write dominant structure of recount writing in standard written English.

The objectives of this research are to know the effects of students' vocabulary and grammar mastery towards English recount writing skill. At the last, the result of research is supposed to be capable to make better the researcher's intellectual about the effects of vocabulary and grammar mastery to recount writing skill and apply all theories that researcher gets while teaching learning activities.

Mastery in one thing can be done through various sources, it could be from the source of learning and not learning. Mastery of one can be affect another person about what he thinks and then keeps it in mind so that it can be used at any-time. Therefore, Bloom said: "the mastery of an activity that is 
acquired through the learning process" (Bloom 1954: 293). In this case the more information the students received, the more mastery they will be.

In line with the above mastery, one of the requirements that a person can now, understand and use words - words properly, speaking activities, either orally or in writing. In other words, a person required to be able to dominate the vocabulary well. While the vocabulary can be generally defined as the number of words - words of a person.

Vocabulary has its definition which is identified as stock of words or list of stated words orderly (Barnhart, 2008). According to Nasution (1985: 26), vocabulary is (a) all the words contained in a language, (b) the words are controlled by one or the words used by a multitude of people from the same neighborhood, (c) the words used in a field of science, (d) lists a number of words and phrases of a language alphabetically arranged and accompanied by a statement boundary.

Vocabulary may be an element of language that consists all the knowledge concerning which means and use of the word. Based on Keraf (1984: 24) a whole vocabulary of words are owned by the language. Beside it, vocabulary is additional just a listing of words. It is word, that means could be a slippery conception. Some words could seem to be straightforward to check with one factor and so (Hermer, 2002). Devies (in Allen, 2006: 5) claims that vocabulary knowledge is related to and affects comprehension. Similar to the previous to the previous statement, why vocabulary is important because comprehension improves when you know what the words mean.

Moreover, vocabulary data is accepted as basic parts of mastering second language. Thus, the goals of language testing is to assess learners in understanding and recognizing the words they speak within the second language successfully (Schmitt, 2000).
Vocabulary is all the words contained in a language. Thus, all the basic words, affixed words, repeated words and compound words in one language vocabulary, may be cited as the one language. Vocabulary is controlled by a person or group of people in the same environment.

Mastery of the vocabulary can be distinguished by two angles, namely quantitative and qualitative angles. The use of vocabulary is quantitatively meaningful

vocabulary covers all lexical units are known and understood.

the paradigm, or pattern of word formation to enable them to create new words and meanings get finer sensibilities. This means that the formation process word here is the same as the change in meaning.

English grammar is one of the important parts that students need to master when studying English language. The Longman Dictionary of Contemporary English defines grammar as "the study of use of the rules by which word change their forms and are combined into sentences".

Grammar is focused with the form of science and auditory communication. It also concerns on syntax and morphology within English sentence (Carter and McCarthy, 2008: 2).

Scott Thornbury (2007:1) said that grammar is learning about how the language formed and structured. The analysis of grammar usually occurred at sentence level, so it can be described that grammar is a description of the rules on how the sentences are formed. Rivers (1981:63) defines grammar is the rules of language started in exceedingly language which is hard to keep it in mind, with several exception appended to every rule. 
In linguistics units, grammar describes the structure of a language and provide rules on how words and phrases are combined to form sentences in the language (Richards et al, 1985: 125). Thus, grammar plays a crucial role in the developing and making the meaning of sentences to be properly understood by the listeners and it functions as a system in a language.

Harmer (2002: 12) stated that words can be placed vary in sentences and perform different meaning within sentences is nothing but the role of grammar. If grammar rules are ignored or carelessly used, the message that is expected to be conveyed may not be clear.

When learning language, students need to know the grammar or the structure of the language well for different language has different grammatical formula and it affect the meaning and the cohesion of the language. Therefore, grammar or structure has important role in conducting communication. By learning structure correctly, so we will have good communication and the language will be acceptable. Otherwise, it will be miscommunication without it.

As grammar plays an important role in English, teaching English by stressing into the structure is needed. Although some experts issued teaching English that is focusing on structure, the curriculum nowadays has placed grammar into a rightful place. Many people believe that learning grammar is important. Richards (2008) believes that the improvement of language will be severely constraint if the learners have no proper knowledge on grammar.

While Carter and Mc.Carthy (2008:6,2d) stated that grammar as structure means: What rule does one to know in order to construct a sentence or clause appropriately? Grammar does not exist separately from other levels of language; there is closed link between grammar and lexis that is given to the meaning, structure and formation on individual words.

By the basic theory of grammatical explaining above, there are the same opinions that grammatical is partly the study of what forms are possible in language. The field of grammar is often divided into two domains, morphology, and syntax those are represented in tenses. The former focus on the structure of words, dealing with such matters as inflectional endings and the way words can be built a small unit the letter focusing on the structure on sentences.

Grammatical mastery includes tenses. There are many tenses of the verb in English. Tense is one of the elements in English that is difficult to be understood and mastered by the students who learn English because tense does not have in Indonesian grammatical.

In short, it can be said that the tenses are verb changing depends on the time and nature of happening. All sentences in English cannot be separated from these tenses element because all sentences must have something to do with time, either past, present and the future.

Tense is a variation in the form of verb to indicate the time of the action that is expressed by the speaker. There are two kind of tenses in English, they are the past and non-past. Verb can be either in the non-past or the past.

In the non-past, there are two forms: one is used for the first and the second persons and all plural nouns and pronouns, while the other is used for the third person singular and tell singular nouns and pronoun.

The non-past tense is used for anything that is not past, and therefore includes the present and the future. The same verb forms which we used for the present tense may be used for the future with the time differentiation indicated 
not by the verb form but by the adverbials or time phrases used.

Gerot and Wignell (1998: 17) said that genre is culturally specific text people the Junior High School students in Indonesia is recount.

Recount text concerns to someone or community's experience in the past. It can be about the writer's journeys or activities that are occurred in the past. According to Gerrot (cited in Hartono (2005: 6) recount reconstructs the accumulation of skills in the past which could retell events as well as incidents in the long time ago. In line with thw above definition, Echols (1975: 471), defined recount text concerns about one's risk and exciting activities that happened in the past. Meanwhile Anderson (1997: 48) defined recount as speaking or writing concerning past events or activities which someone felt or faced it and retell it.

A recount is a genre of a text which has a social role and the function of the text is to tell the readers about "what happened". A social recount has an aim as a documentation of a series of events and the significant value of the events. In addition, recount describe the audience about something that is occurred. The goal of recount is to inform readers about a sequence of events to entertain them. Therefore, a recount may include the writer's perspective and feeling on the event that is told. Recount is divided into three types. The types of recount are described below.

\section{a. Personal Recount Text}

Personal recount is a recount text that focus on the personal activity or event that is experienced or concerned in directly by the speaker, (e.g. anecdote, diary). The characteristics of personal recount are:

1) I and we as the first pronoun are mostly found

2) Responses personally to the events can be included, particularly at the end
3) To add humor or interest, details are often given

b. Factual Recount Text

Factual recount is a recount that

concerns with the particulars of an accident (e.g. report of science experiment, police report, news report). The characteristics of factual recount are:

1)The pronouns of the third person are mostly expected, like he, she, it, and they

2) The reader reconstructs the activity or incident accurately by choosing the details event or time to help him

3) Generally the ending describes the result of the activity (e.g. in a science experiment

4) Mention of feeling personally in probability cannot be applied.

5) Details of time, place, and manner are close to be exactly expressed

6) Descriptive details may also be

needed to supply information precisely (e.g. a man with a red shirt, brown shoes and long his, weighing 75 kilos and approximately $189 \mathrm{~cm}$ tall)

7) It requires passive voice (e.g. the breaker was filled with water)

8) Explanation and satisfaction are eligible to be used.

c. Imaginative Recount Text Imaginative recount is a recount that brings on associate fanciful role and gives details events (e.g. a day in the life of a Roman Slave: how I invited ....) Board of studies (1998b:287) the steps for constructing of written recount text are:

1) The first paragraph that offers background data concerning who, what, where and when. It is known as an orientation 
2) A record of events typically recounted in written chronological orderly, name, event 1 , event 2 , and event 3

3) A private comment and or critical remarks, which are interspersed throughout the record of events named evaluation

4) A reorientation that "rounds off" the sequences of incidents or retell about what was going on at the end

Board of studies (1998b:287) the language features usually found in a recount:

1) The use of noun and pronoun to

2) The usage of past action verbs that refer the events

3) The usage of past tense to find events in which relates to speaker's or writer's time

4) Conjunctions and cohesive devices are mostly used to sequence the event

5) Adverb and adverbial phrase are frequently used to describe place and time

6) The usage of adjectives to explain noun

In creating of functional grammar, board of studies (1998b: 287) the crucial grammatical patterns of recount generally include:

1) Specific participants

2) The use of action verb or material method

3) Time and place

4) Past tense is required and concentrate on temporal sequence

This research is done in regency of Tangerang, province of West Java. This research is done at class eight at Private Junior High School of Strada Bhakti Mulia, Private Junior High of Al Hikma, and Private Junior High of Prima Nusantara. Time of research is in May 2014 until August 2014.

In this research, the writer used survey method that is the method tries to describe or give some descriptions about the effects from one variable to the others. This survey research is meant to get the description of how great correlation coefficient among the variables gone on continued with regression significant test and linearity for the sake of prediction.

The populations in this research are all the students of class 8 of Junior High School of Strada Bhakti Mulia, Junior high School of Al Hikma and Junior High School of Prima Nusantara, and the samples are taken as much as forty students by using sample random technique.

The Techniques of Collecting Data

\section{Primary Data}

Primary data were collected which came from the object. Further primary data was processed by the researcher to generate the data analysis. In this study, the primary data is the influence of student's vocabulary and grammar mastery towards

English recount writing skill at private Junior High School in Tangerang. Primary data can be collected by data collection instruments such as questionnaires. The questionnaire contains several questions regarding the indicators of student's vocabulary and grammar mastery towards English recount writing skill at private Junior High School in Tangerang.

\section{Secondary Data}

Secondary data collection conducted through literature research (library research) by studying the sources of literature or important documents, either

from institutions and management textbooks. Secondary data were taken from the agency include a general description and value of the school. 
This research using three instruments of questioners, they are: (1) The Students' Vocabulary, (2) Grammar mastery, (3) English recount writing skill at Private Junior High School in Tangerang. These three instruments are developed themselves by arranging the grill and questions for every variable.

Having collected all the data, the researcher tabulated and analyzed to answer the question of this research. The Tabulation process is accomplished by using SPSS version 17.0 for windows. In a descriptive analysis, the data presentation technique will be done in the form frequency distribution tables, polygon graphs and histograms for each study variable. In addition, each group of data will be processed and analyzed to measure the central of tendency and the position of mean, median, and medusas well as the range of deviation, variance, standard deviation and kurtosis. For the calculation of this activity the researcher used SPSS version 17.0 for windows.

Test requirements of data analysis is used in order to determine whether the data has been collected for further analysis is feasible or not by using statistical tools. The test which was performed is data normality's test and linearity regression's test. In this study the overall analysis was carried out by a computer program of SPSS version 17.0 for windows

The analysis of research hypothesis test is done by using two-tailed ANOVA (Analysis of Variance) technique. The twotailed ANOVA is a technique to analyze the data of the research byusing SPSS version 16.0 for windows. The criteria of testing are achieved by seeing the value of significance (Sig).

Accept $\mathrm{H}_{0}$ : the $\mathrm{H}_{0}$ will be accepted only when the significance value is $<0.05$. When the significant value is lower than 0.05 , it means that there is an effective result between the variables.
Accept $\mathrm{H}_{1}$ : when the significance value is higher than 0.05 , it means that there is no significant effect between the variable.

\section{FINDING AND DISCUSSION}

This study will be present the results of research on the analysis and discussion of results of research that includes data processing description, the testing requirements analysis, hypothesis testing research, interpretation and discussion of findings and limitations of the study.

In analyzing the data directed at testing the hypothesis, which begins with a description of the research data of the three variables in the form of frequency distributions, measures of symptoms and the histogram center and determine the regression equation. To illustrate the influences of each variables is done by simple regression analysis and to describe the overall effect of variables is jointly used multiple regression analysis. Testing assumptions for regression testing parameters on the study data conducted by a test of normality with the Liliefors method, a test of co-linearity, and also test of heterogeneousness.

1. The Description of Data of The Students'

Vocabulary.

The variable of Students' vocabulary of

English in this study is the score obtained from the

test containing 20 multiple choice items that indicate students' vocabulary mastery

We can make frequency distribution and histogram for the variable of Student's Achievement of English which is useful for completing data research.

\section{The Description of Data of The Grammar Mastery.}

The variable of grammar mastery is scores obtained based on students' grammar mastery. To measure students' grammar 
mastery the researcher posed the research instrument consist of 25 multiple choice item questions.

Table 1.

Description of Grammar Mastery Statistics Teacher Performance

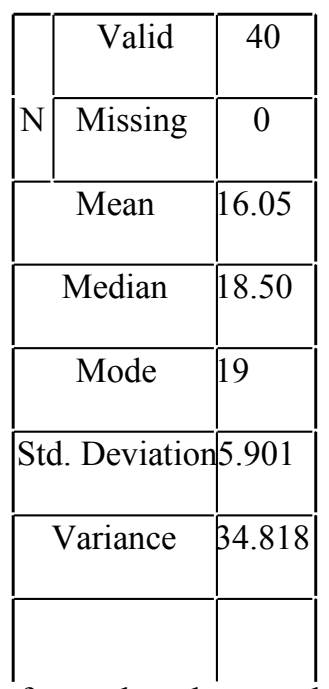

Then from the above table, it can be made frequency of distribution and histogram for the variable of teacher's performance at junior high school in Tangerang which is useful to complete the presentation of data.

3. The Description of Data of English Recount Writing skill.

The variable of English recount writing skill in this study is score on the writing of students to English subjects. To measure the English recount writing skill, the researcher posed the research instrument consist of one topic.

\section{The Effects of Students' Vocabulary}

\section{(X1) and Grammar Mastery}

(X2) towards Students' English

Recount

Writing Skill (Y)

Hypothesis 1

$\mathrm{H} 0: \beta \mathrm{y} 1=\beta \mathrm{y} 2=0$, means that there are no effects of

students' vocabulary and grammar mastery towards students' English recount writing skill.

$\mathrm{H} 1: \beta \mathrm{y} 1 \neq 0$ and $\beta \mathrm{y} 2 \neq 0$, means that there are effects

of students' vocabulary and grammar mastery towards students' English recount writing skill.
Based on the table 4.6 model summary tells the amount of relationship between perception on teacher competence and grammar mastery towards students' English recount writing skill that is calculated by correlation coefficient is 0.987 or (ry12 = 0.987 ) which shows a very strong effects. On the other hand, the contribution simultaneously of perception on teacher competence and grammar mastery towards students' writing skill is R2 $\mathrm{x} 100 \%$ or $0.9872 \times 100 \%=97,4 \%$ the rest is $2,6 \%$ for determined by the other factors.

Meanwhile, for the test hypothesis by using regression analysis, it is found that calculation result that is appeared on the table 4.5 and 4.6 which concludes the similarity of regression line which presents the effects of perception on teacher competence and grammar mastery towards students' writing skill is $=22.231$

$+0.283 \mathrm{X} 1+2.688 \mathrm{X} 2$.

\section{Meanwhile the significance test of}

regression line is by attended of calculation on the table 4.6. The regression significance criteria is "if

sig $<0.005$ means $\mathrm{H} 0$ is rejected" or observed $>\mathrm{F}$ table means $\mathrm{H} 0$ is rejected", meaning that the regression coefficient is significant, on the other words, there is a significant effect. The score of sig is the numbers that are stated on the column sig on the table 4.6. the score of Fobserved is stated on the number of the column $\mathrm{F}$ on the table of 4.6. Meanwhile the score Ftable is the score distribution table $\mathrm{F}$ for the real standard of $5 \%$ the degree of numerator is $(\mathrm{k})=2$ and degree of denominator is (n-k-1) $=40-2-1=37$ which $\mathrm{n}$ is the amount of respondents (40 students), $\mathrm{k}$ is the amount of free variables (X1 and X2).

Table 4.11 shows that that the convention $\mathrm{Sig}=$ 0.000 and Fobservedis 679.878, Meanwhile the Ftable $=3.25$. Because the score of Sig $<0.05$ $(0.000<0.05)$ and Fobserved $>$ Ftable $(586.387$ $>3.25$ ) means $\mathrm{HO}$ is rejected meaningthat

student's English recount writing skill. From 
the result of correlation test of regression, it can be concluded that there are the effects student's vocabulary and grammar mastery towards student's writing skill.

\section{The Effect of Students' Vocabulary (X1) towards Students' English Recount Writing Skill (Y)}

Accordingly, the calculation of data analysis concludes that the contribution of variable student's vocabulary (X1) towards students' writing skill (y) is the score of Sig $=0.124$ and tobserved $=1.574$ meanwhile ttable $=1.69$. Because of the score of $\mathrm{Sig}>0.005(0.124>0.05)$ and tobserved <table $(1.574<1.69)$ means $\mathrm{H}_{0}$ is meaning that there is no significant effect between students' vocabulary towards students' writing skill. From the test of correlation and regression it can be concluded that there is no effect of students' vocabulary towards students' writing skill.

\section{The Effect of Grammar mastery (X2) towards Students' English Recount Writing Skill (Y)}

The effect of grammar mastery towards student's writing skill based on this research data analysis can be interpreted that give strong effect for the respondent. It is proven by the result that is the score of Sig $=0.000$ and tobserved $=14.718$ meanwhile ttable 1.69 . Because of the score of Sig $<0.005$ $(0.000<0.05)$ and tobserved $>$ ttable $(14.718>1.69)$ means $\mathrm{H} 0$ is rejected it meaning that there is a significant effect between grammar mastery towards students' English recount writing skill. From the test of correlation and regression it can be concluded that there is an effect of grammar mastery towards students' English recount writing skill.

\section{CONCLUSION}

There are several conclusions after taking the data analysis, they are:

1. There are significant effects of students' vocabulary (X1) and grammar mastery (X2) towards students' English recount writing skill (Y).
2. There is no significant effect of students' vocabulary mastery towards students' English recount writing skill (Y).

3. There is a significant effect of grammar mastery toward students' writing skill (Y). From the test of correlation and regression it can be concluded that there is an effect of grammar mastery towards students' English recount writing skill.

\section{REFERENCES}

Abdullah, Ibrahim Suparman. 2012. Aplikasi Komputer dalam Penyusunan Karyallmiah (SPSS, MINITAB, dan LISREI) Tangerang: Pustaka Mandiri.

Akhadiah, Sabarti et al. 1986. Menulis II. Jakarta:Universitas Terbuka.

Anderson, R. C, \& Freebody, P. 1981. Vocabulary Knowledge. In J. Guthrie(Ed), Comprehensioned teaching: Research reviews (pp.77-117) .Newmark: DE: International Reading Association.

Bloom, B.S, 1956. Taxonomy of Educational Objectives. The Classification Goals (Handbook 1. Cognitive Domain), New York: Longman Green.

Carter, Ronald and Michael McCarthy, 2006. Cambridge Grammar of English: $A \quad$ Comprehensive Guide (Paperback), Cambridge: Cambridge University, Press.

Effendi, Sofian and Tukiran, 2012. Metode

Penelitian Survey. Jakarta: LP3ES.

Gerot and Wignell, 1998. Making Sense of Functional Grammar, An IntroductoryWorkbook, Cammeray, NSW, Antipodean Educational Enterprises.

Hedge, Tricia, 2003. Teaching \& Learning in the Language Classroom, UK:OUP.

Keraf, Gorys, 1984. Diksi dan Gaya Bahasa. Jakarta: Gramedia. 
Muliono, Anton, 1964. On Grammatical Categories in Indonesian. Thesis M.A:

Cornell University 